DOI: $10.6060 / \mathrm{mhc} 181109 \mathrm{~s}$

\title{
Features of Inverted Tetrasulfophenylporphyrin Protonation. Crucial Role of Hydrogen Bonds
}

\author{
Vladimir B. Sheinin, ${ }^{a}$ Olga M. Kulikova, ${ }^{a}$ and Oscar I. Koifman ${ }^{\mathrm{a}, \mathrm{b}}$ \\ ${ }^{\mathrm{a}}$ G.A. Krestov Institute of Solution Chemistry of the Russian Academy of Sciences, 153045 Ivanovo, Russia \\ 'Ivanovo State University of Chemistry and Technology, 153000 Ivanovo, Russia \\ ${ }^{\circledR}$ Corresponding authorE-mail:vbs@isc-ras.ru
}

\begin{abstract}
Diprotonation equilibria of inverted platform of tetraanionic 5,10,15,20-tetrakis(4'-sulfophenyl)-2-aza-21carbaporphyrin, $\boldsymbol{H}_{2} \mathbf{I P}\left(\mathrm{PhSO}_{3} H\right)_{4}$, with perchloric acid in water was studied using DFT/B3LYP/6-31++G(d,p) and spectropotentiometric titration methods. In aqueous solution this porphyrinoid exists in the form of NH tautomer $\boldsymbol{H}_{2} \boldsymbol{I}_{(i)} \boldsymbol{P}\left(\mathrm{PhSO}_{3}^{-}\right)_{4}$ with an inverted pyrrolenine ring, which is stabilized by bifurcated intramolecular hydrogen bonds between two pyrrole hydrogens and one pyrrolenine nitrogen. Intramolecular hydrogen bonds protect intramolecular hydrogen-bonding sites from intermolecular interactions. For this reason, the external nitrogen atom is protonated first, and then the internal one is protonated. The second proton switches the intramolecular hydrogen bonds to intermolecular hydrogen bonds. Diprotonated platform $\mathbf{H}_{4} \mathbf{I P}^{2+}\left(\mathrm{PhSO}_{3}\right)_{4}{ }_{4}$ has the geometry of elastic 1,3-alternate, which is a molecular and anionic receptor. The equilibrium of the second stage protonation in water is completely shifted to the aquacomplex $\left[\mathrm{H}_{4} \mathbf{I P}^{2+}\left(\mathrm{PhSO}_{3}^{-}\right)_{4}\right]\left(\mathrm{H}_{2} \mathrm{O}\right)_{2}$, which is formed due to the hydrogen and electrostatic binding of the solvent molecules on both receptor sites. Aquacomplex $\left[\mathbf{H}_{4} \mathbf{I P}^{++}\left(\mathrm{PhSO}_{3}^{-}\right)_{4}\right]\left(\mathrm{H}_{2} \mathrm{O}\right)_{2}$ is a monomer of linear J-aggregates self-assembly. The driving force of J-aggregates assembly is the formation of stronger anionic complexes as a result of water molecules intermolecular replacement by sulfonate groups of monomers.
\end{abstract}

Keywords: Tetrasulfophenyporphyrin, inverted ( $N$-confused) porphyrins, protonation, hydrogen bond, $J$-aggregates.

\section{Особенности протонирования инвертированного тетрасульфофенилпорфирина в воде. Критическая роль водородных связей}

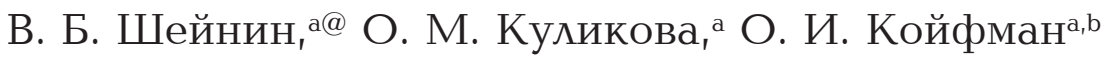 \\ а Институт химии растворов им. Г.А. Крестова Российской академии наук, 153045 Иваново, Россия \\ ${ }^{\mathrm{b}}$ Ивановский государственный химико-технологический университет, 153000 Иваново, Россия \\ ${ }^{\circledR}$ E-mail: vbs@isc-ras.ru
}

\begin{abstract}
Методами DFT/B3LYP/6-31++G(d,p) и спектропотенииометрического титрования исследованы равновесия дипротонирования инвертированной платформы тетрааниона 5,10,15,20-тетракис(4'-сульфофенил)2-аза-21-карбапорфина $\boldsymbol{H}_{2} \boldsymbol{I P}\left(\mathrm{PhSO}_{3} \mathrm{H}_{4}\right.$ хлорной кислотой в воде. В водном растворе этот порфириноид находится в виде $\mathrm{NH}$-таутомера $\boldsymbol{H}_{2} \boldsymbol{I}_{(i)} \boldsymbol{P}\left(\mathrm{PhSO}_{3}^{-}\right)_{4}$ с инвертированным пирроленинным кольцом, который стабилизируется бифуркатными ВМВС между двумя пиррольными водородами и одним пирролениновым азотом. ВМВС защищают внутримолекулярные центры водородного связывания от межмолекулярных взаимодействий. По этой причине первым протонируется внешний атом азота, а внутренний протонируется вторым. Второй протон переключает ВМВС на ММВС. Дипротонированная платформа $\boldsymbol{H}_{4} \mathrm{IP}^{2+}\left(\mathrm{PhSO}_{3}\right)_{4}{ }_{4}$ имеет геометрию упругого 1,3-альтерната, который обладает свойствами молекулярного и анионного рецептора. Равновесие второй ступени протонирования в воде полностью сдвинуто к аквакомплексу $\left[\mathbf{H}_{4} \boldsymbol{I P}^{2+}\left(\mathrm{PhSO}_{3}^{-}\right)_{4}\right]\left(\mathrm{H}_{2} \mathrm{O}\right)_{2}$, который образуется за счет водородного и электростатического связывания молекул растворителя в двух сайтах рецептора. Аквакомплекс $\left[\boldsymbol{H}_{4} \boldsymbol{I P}^{++}\left(\mathrm{PhSO}_{3}^{-}\right)_{4}\right]\left(\mathrm{H}_{2} \mathrm{O}\right)_{2} n_{\text {nред- }}$ ставляет собой мономер самосборки линейных J-агрегатов. Движущей силой образования J-агрегатов
\end{abstract}


является образование более прочных анионных комплексов в результате межмолекулярного замещения молекул воды сульфонатными группами мономеров.

Ключевые слова: Тетрасульфофенилпорфирин, инвертированные порфирины, протонирование, водородная связь, J-агрегаты.

\section{Introduction}

The key part of supramolecular porphyrin assemblies in nature inspires researchers to developed biomimetic systems for a wide range of applications. The molecular structure of porphyrins is easily modified both on the core and periphery, providing a structural complementary of monomer units leads to supramolecular selfassembly. ${ }^{[1-12]}$ Understanding such processes attracted great interest due to the apparent potential of the functional nanomaterials self-assembly strategy, which opens up the splendid perspectives for the directed design of chemosensors, molecular switches, luminescent sensors, photon wires and catalysts. To date, a wide range of regular discrete porphyrin nanostructures such as nanotubes, fibers, wheels, spheres, plates, etc. have been obtained. ${ }^{[13,14]}$ Watersoluble derivatives of 5,10,15,20-tetrakis(4'-sulfophenyl) porphyrin $\mathbf{H}_{2} \mathbf{P}\left(\mathrm{PhSO}_{3} \mathrm{H}\right)_{4}$ are widely used as building blocks for such structures, due to the successful combination of availability and good solubility of such compounds in water. Promising derivatives of $\mathbf{H}_{2} \mathbf{P}\left(\mathrm{PhSO}_{3} \mathrm{H}\right)_{4}$ are watersoluble porphyrinoids with inverted pyrrole ring, such as 5,10,15,20-tetrakis(4'-sulfophenyl)-2-aza-21-carbaporphyrin $\mathbf{H}_{2} \mathbf{I P}\left(\mathrm{PhSO}_{3} \mathrm{H}\right)_{4}$ and 2- $\mathrm{N}$-methyl-5,10,15,20-tetrakis(4'sulfophenyl)-2-aza-21-carbaporphyrin $\mathbf{H}_{2} \mathbf{M e I P}\left(\mathrm{PhSO}_{3} \mathrm{H}\right)_{4}$.

Investigations of inverted porphyrins properties, including aqueous media, have been carried out since their discovery due to the unique structure of these compounds. [15-25] Previously it was shown that diprotonated inverted platform possesses the properties of anionic receptor, ${ }^{[8,26]}$ the zwitterions $\mathbf{H}_{4} \mathbf{I P}^{2+}\left(\mathrm{PhSO}_{3}^{-}\right)_{4}$ and $\mathbf{H}_{3} \mathbf{M e I P} \mathbf{P}^{2+}\left(\mathrm{PhSO}_{3}^{-}\right)_{4}$ are able to form supramolecular $J$-aggregates, stable in $\mathrm{pH}$ neutral aqueous solutions. ${ }^{[21,27]}$

In this work we presented the results of theoretical and experimental studies of $\mathbf{H}_{2} \mathbf{I P}\left(\mathrm{PhSO}_{3}^{-}\right)_{4}$ diprotonation equilibria, resulted in formation of aquacomplex $\left[\mathbf{H}_{4} \mathbf{I P}^{2+}\left(\mathrm{PhSO}_{3}^{-}\right)_{4}\right]\left(\mathrm{H}_{2} \mathrm{O}\right)_{2}$, which is $J$-aggregates selfassembly monomer.

\section{Experimental}

All commercially available solvents and reagents were used without further purification: $N, N$-Dimethylformamide $(0.01 \%$ $\mathrm{H}_{2} \mathrm{O}$, Panreac), dichloromethane (for HPLC, $99.8 \%$, Acros Organics), distilled water (ISC RAS), perchloric acid (70\%, ASC reagent, Aldrich). 5,10,15,20-Tetraphenyl(2-aza-21-carbaporphyrin, $\left(\mathbf{H}_{2} \mathbf{I P}(\mathrm{Ph})_{4}\right),{ }^{[28]} \quad 5,10,15,20$-tetrakis(4'sulfophenyl)-2-aza-21carbaporphyrin $^{[27]}$ were synthesized according to reported procedures. Micropipette with scale division value $6.3 \cdot 10^{-5} \mathrm{~mL}$ was used for titration experiment. The absorbance and fluorescence spectra were recorded synchronous at $25^{\circ} \mathrm{C}$ in $1 \times 1 \mathrm{~cm}$ optical quartz cells using a fluorescence spectrophotometer (Avantes AvaSpec 20482 , Netherlands) equipped with a qpod $\subset$ (Quantum). The basicity constants were calculated by the fitted parameters method using SigmaPlot ${ }^{\circledR}$ (Systat Software Inc. (SSI)) software. Quantum chemistry calculations were performed at the B3LYP level of density functional theory DFT/ B3LYP/6-31 ${ }^{++} \mathrm{G}(\mathrm{d}, \mathrm{p})$ using Gaussian software package. ${ }^{[29]}$

\section{Results and Discussion}

\section{Inversion of Tetraanion $\mathrm{H}_{2} \mathrm{P}\left(\mathrm{PhSO}_{3}^{-}\right)_{4}$ Porphyrin Platform}

Dissolution of $\mathbf{H}_{2} \mathbf{I P}\left(\mathrm{PhSO}_{3} \mathrm{NH}_{4}\right)_{4}$ (as well as $\left.\mathbf{H}_{2} \mathbf{P}\left(\mathrm{PhSO}_{3} \mathrm{NH}_{4}\right)_{4}\right)$ in water leads to tetraanion $\mathbf{H}_{2} \mathbf{I P}\left(\mathrm{PhSO}_{3}^{-}\right)_{4}$ formation based on substituted by four phenylsulfonate radicals in porphyrin platform. These peripheral substituents are in inductive interaction with inverted platform $\mathbf{H}_{2} \mathbf{I P}$, which exhibits electron-withdrawing effect, and weakly coupled with each other. The dissociation constants values of the peripheral sulfonic groups of $\mathbf{H}_{2} \mathbf{I P}\left(\mathrm{PhSO}_{3} \mathrm{H}\right)_{4}$ are unknown, but they are comparable with those for benzenesulfonic acid $\left(\mathrm{p} K_{\mathrm{a}}=0.7\right)$. Since the platform $\mathbf{H}_{2} \mathbf{I P}$ in water is diprotonated first, and the platform electron-withdrawing effect increased in the series $\mathbf{H}_{2} \mathbf{I P}, \mathbf{H}_{3} \mathbf{I} \mathbf{P}^{+}, \mathbf{H}_{4} \mathbf{I} \mathbf{P}^{2+}$ with positive charge increasing, all four phenylsulfonate groups in acidic aqueous solutions will be ionized. For this reason,

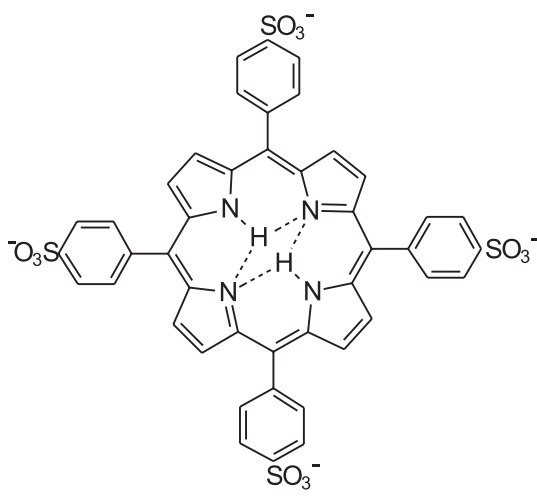

$\mathbf{H}_{2} \mathbf{P}\left(\mathrm{PhSO}_{3}^{-}\right)_{4}$

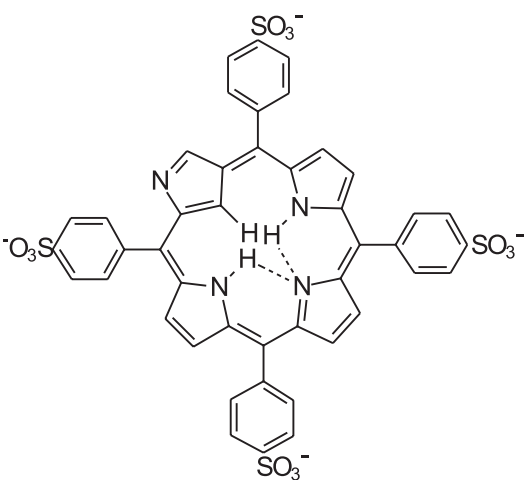

$\mathbf{H}_{2} \mathbf{I}_{(\mathrm{i})} \mathbf{P}\left(\mathrm{PhSO}_{3}^{-}\right)_{4}$

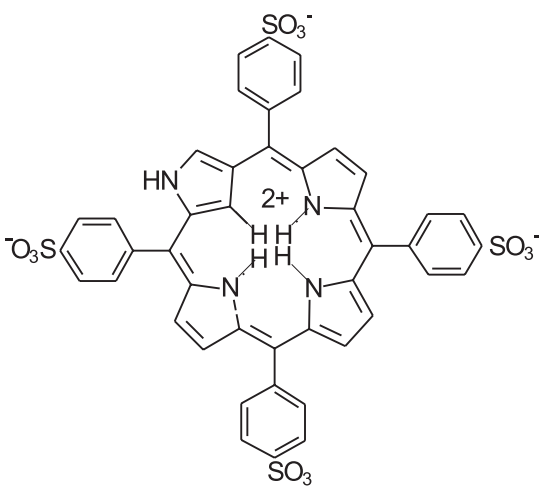

$\mathbf{H}_{4} \mathbf{I P}^{2+}\left(\mathrm{PhSO}_{3}^{-}\right)_{4}$ 
in presented article we consider the processes exclusively involving tetraanions $\mathbf{H}_{2} \mathbf{I} \mathbf{P}\left(\mathrm{PhSO}_{3}^{-}\right)_{4}, \quad \mathbf{H}_{2} \mathbf{P}\left(\mathrm{PhSO}_{3}^{-}\right)_{4}$ and the products of the porphyrin platform protonation.

The porphyrin platform $\mathbf{H}_{2} \mathbf{P}$ is formed by different in structure pyrrole (A) and pyrrolenine (B) rings (Figures 1, 2(1)). As a result of the pyrrole or pyrrolenine ring inversion, two NH-tautomers $\mathbf{H}_{2}$ IP with a different combination of three internal and one external centers of H-bonding (HB) are formed. Inversion of the pyrrole ring results in a $\mathbf{H}_{\mathbf{2}} \mathbf{I}_{(\mathrm{e})} \mathbf{P}$ tautomer formation with an external HB-donor NH-group and two bifurcated intramolecular hydrogen bonds (IMHB) of the NHN type. Pyrrolenine ring inversion results in a $\mathbf{H}_{\mathbf{2}} \mathbf{I}_{(\mathbf{i})} \mathbf{P}$ tautomer with an external HB-acceptor nitrogen atom and two bifurcated IMHB of the HNH type.

Enthalpy dissipations due to $\mathbf{H}_{2} \mathbf{P}\left(\mathrm{PhSO}_{3}^{-}\right)_{4}$ porphyrin platform inversion are 13.01 and $17.34 \mathrm{kcal} / \mathrm{mol}$ for $\mathbf{H}_{\mathbf{2}} \mathbf{I}_{(\mathbf{i})}$ $\mathbf{P}\left(\mathrm{PhSO}_{3}^{-}\right)_{4}$ and $\mathbf{H}_{2} \mathbf{I}_{(\mathbf{e})} \mathbf{P}\left(\mathrm{PhSO}_{3}^{-}\right)_{4}$, respectively. Thus, in the absence of medium effects, the tautomer $\mathbf{H}_{2} \mathbf{I}_{(\mathbf{i})}$ $\mathbf{P}\left(\mathrm{PhSO}_{3}^{-}\right)_{4}$ is more stable than $\mathbf{H}_{2} \mathbf{I}(\mathrm{e}) \mathbf{P}\left(\mathrm{PhSO}_{3}^{-}\right)_{4}$ by 4.33 $\mathrm{kcal} / \mathrm{mol}$, due to a more effective IMHB. Two opposite types of specific solvation external centers are the cause of the dependence of inverted porphyrins tautomeric equilibrium from solvents HB-donor $(\Sigma \beta)$ and HB-acceptor $(\Sigma \alpha)$ properties. $^{[30,31]}$

Conjugated tautomers of inverted porphyrins possessed the different UV-Vis spectra, ${ }^{[32]}$ which general view was used for identification of $\mathbf{H}_{2} \mathbf{I}_{(\mathrm{i})} \mathbf{P}\left(\mathrm{PhSO}_{3}^{-}\right)_{4}$ and $\mathbf{H}_{2} \mathbf{I}_{(\mathrm{e})}$ $\mathbf{P}\left(\mathrm{PhSO}_{3}^{-}\right)_{4}$ tautomers in solutions (Figure 1).

In conditionally inert DCM $(\Sigma \alpha=0.10$ and $\Sigma \beta=0.11)$, as in the absence of media effects, inner tautomer $\mathbf{H}_{\mathbf{2}} \mathbf{I}_{(\mathbf{i})}$ $\mathbf{P}\left(\mathrm{PhSO}_{3}^{-}\right)_{4}$ is more stable. In amphoteric water, which predominately is HB-donor solvent $(\Sigma \alpha=1.17>\Sigma \beta=0.47)$, the inner tautomer $\mathbf{H}_{2} \mathbf{I}(\mathbf{i}) \mathbf{P}\left(\mathrm{PhSO}_{3}{ }^{-}\right)_{4}$ is supplementary stabilized due to the more effective specific solvation of external pyrrolenine nitrogen. Tautomer $\mathbf{H}_{2} \mathbf{I}_{(\mathbf{e})} \mathbf{P}\left(\mathrm{PhSO}_{3}^{-}\right)_{4}$ is stable in HB-acceptor solvents, e.g. in DMF $(\Sigma \alpha=0, \Sigma \beta=0.74)$ or DMSO ( $\Sigma \alpha=0, \Sigma \beta=0.88)$, which "pull out" the inner proton on inverted platform periphery due to the more effective specific solvation of external NH-group. For investigations in aqueous medium, tautomer $\mathbf{H}_{2} \mathbf{I}(\mathbf{e}) \mathbf{P}\left(\mathrm{PhSO}_{3}^{-}\right)_{4}$ can be fixed by methylation of external NH-bond. ${ }^{[27]}$

\section{Protonation of $\boldsymbol{H}_{2} \boldsymbol{I}_{(i)} \boldsymbol{P}\left(\mathrm{PhSO}_{3}^{-}\right)_{4}$}

\section{Molecular Structure of $\boldsymbol{H}_{2} \mathbf{I}_{(i)} \boldsymbol{P}\left(\mathrm{PhSO}_{3}^{-}\right)_{4}$}

Coordination cage of $\mathbf{H}_{2} \mathbf{I}_{(\mathbf{i})} \mathbf{P}$ platform includes one pyrrole HB-donor NH-group and two pyrrolenine HB-acceptor $\mathrm{N}$-atoms. The intramolecular tightness causes the formation of two bifurcated IMHB of NHN type, which, together with the aromatic system, aspire to keep two pyrrolenine and one pyrrole rings in a coplanar state (Figure 2). The deviation of the interatomic distance from the sum of Van der Waals radii was used as a criterion for the IMHB formation or breaking: HB is formed and strengthened when a negative deviation and breaks when a positive deviation (Table 1). According to second Etter's Rule, ${ }^{[33]}$ IMHB that close sixmembered cycles have an advantage over intermolecular hydrogen bonds and will block intracyclic atoms from interaction with solvents and anions, as well as in porphyrins, where bifurcated IMHB protects the reaction centers of $\mathbf{H}_{2} \mathbf{P}$ and $\mathbf{H}_{3} \mathbf{P}^{+}$platforms from intermolecular interactions with polar solvents and anions. ${ }^{[34-39]}$

The singularity of aromatic tetrapyrrole platforms is the presence of the conventional meso-plane C5C10C15C20, which is only slightly deformed even with a strong distortion of the macrocycle. As a result of intramolecular hydrogen repulsion (IMHR) internal $\mathrm{CH}$-proton escapes from the meso-plane at $0.59 \mathrm{~nm}$, and the inverted
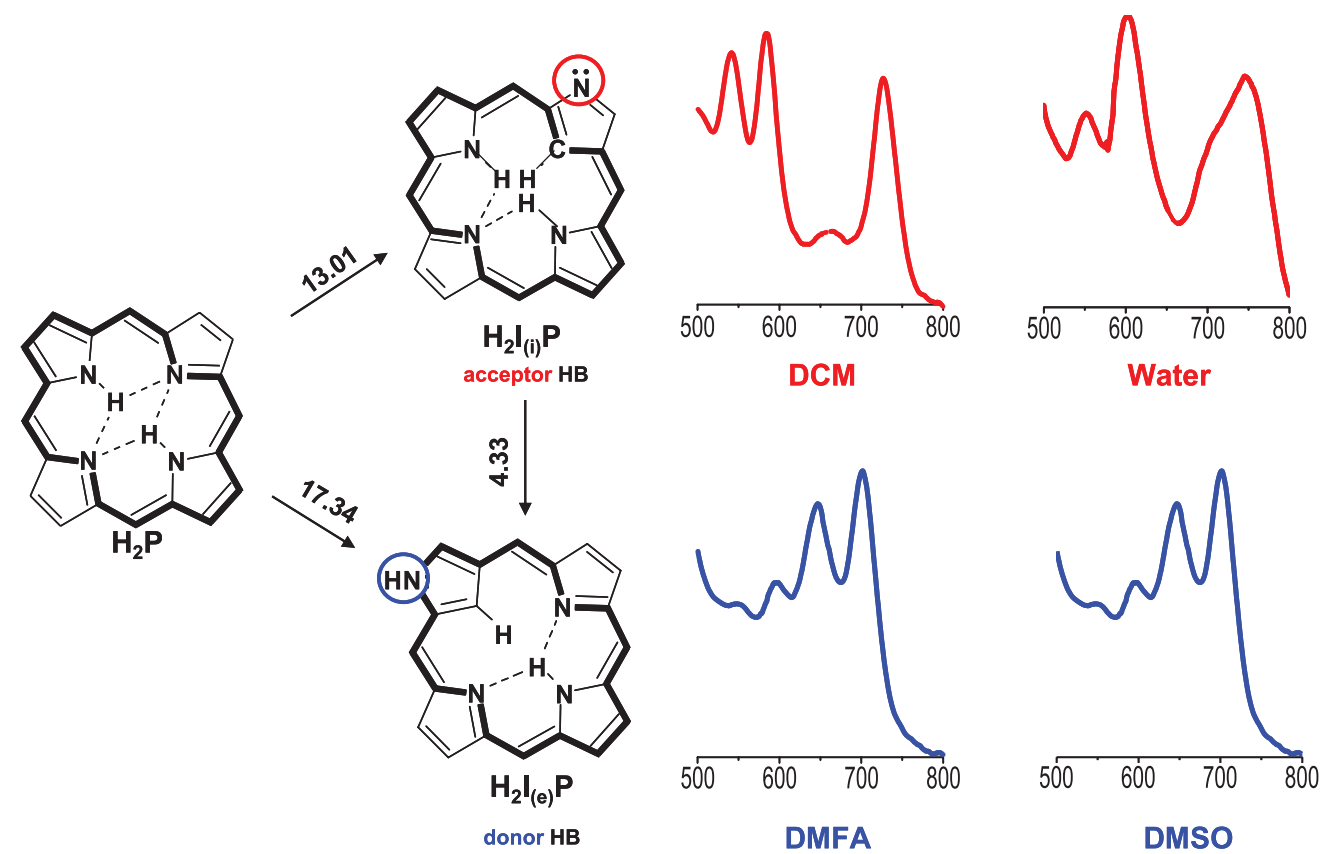

Figure 1. Scheme of $\mathbf{H}_{2} \mathbf{P}\left(\mathrm{PhSO}_{3}^{-}\right)_{4}$ porphyrin platform inversion. meso-Substitutents are omitted for clarity. UV-Vis spectra of inverted NH-tautomers in different solvents are presented on the right side. Bold line shows the aromatic $18 \pi$-electron conjugated cycle. DFTenthalpies of inversion and tautomerization values in $\mathrm{kcal} / \mathrm{mol}$, calculated in gaseous phase, are above the arrows. UV-Vis spectrum in DCM corresponds to $\mathbf{H}_{2} \mathbf{I}_{(\mathbf{i})} \mathbf{P}\left(\mathrm{PhSO}_{3} \mathrm{NBt}_{4}\right)_{4}$. 


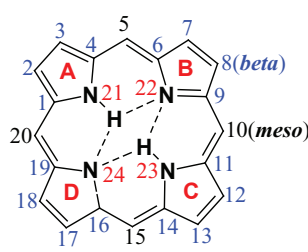

(1)

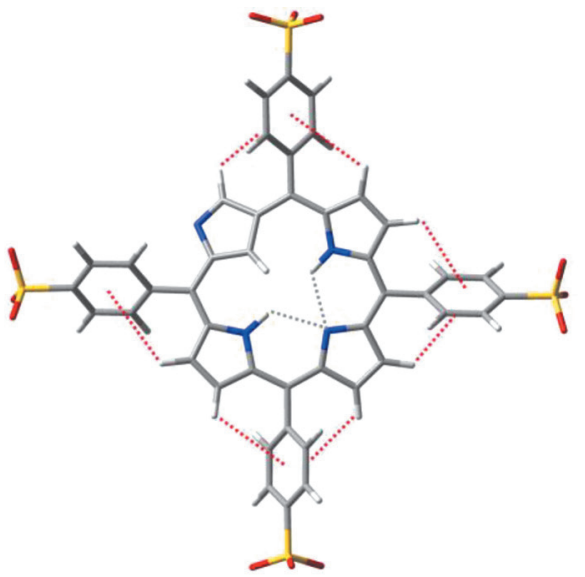

(2)

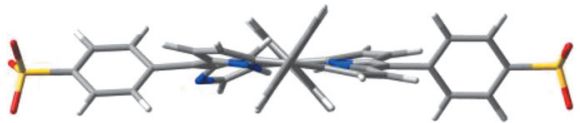

Figure 2. (1) - Indexing of tetrapyrrole platform. (2) - Tetraanion $\mathbf{H}_{2} \mathbf{I P}\left(\mathrm{PhSO}_{3}^{-}\right)_{4}$ DFT-optimized geometry. Gray dashed lines - bifurcated IMHB, red dashed lines $-\mathrm{H}-\pi$ interactions between $\beta$-protons and phenyl rings (distance to phenyl plane center is $3.32 \AA$ ). Sulfonate groups, located perpendicular to the figure plane, are omitted for clarity.

Table 1. Deviations of intramolecular interatomic distances $(\AA)$ from the sum of Van der Waals radii $\left(\mathrm{R}_{\mathrm{w}}\right)(\mathrm{H}(1.16), \mathrm{N}(1.50) \mathrm{O}(1.29))$. $^{[40]}$

\begin{tabular}{|c|c|c|c|c|c|c|c|c|c|c|c|}
\hline \multirow{4}{*}{ Compound } & \multicolumn{6}{|c|}{ IMHR } & \multicolumn{5}{|c|}{ IMHB } \\
\hline & \multirow{2}{*}{\multicolumn{6}{|c|}{$2 \mathrm{R}_{\mathrm{w}}(\mathrm{H})-$ distance $\mathrm{HH}$}} & \multicolumn{5}{|c|}{$\mathrm{R}_{\mathrm{w}}(\mathrm{H})+\mathrm{R}_{\mathrm{w}}(\mathrm{X})-$ distance $\mathrm{H} \cdots \mathrm{X}$} \\
\hline & & & & & & & & & $\cdot \mathrm{N}$ & & $\mathrm{H} \cdots \mathrm{O}$ \\
\hline & $\mathrm{AB}$ & $\mathrm{BC}$ & $\mathrm{CD}$ & $\mathrm{AD}$ & $\mathrm{AC}$ & $\mathrm{BD}$ & $\mathrm{AB}$ & $\mathrm{BC}$ & $\mathrm{CD}$ & DA & \\
\hline $\mathbf{H}_{2} \mathbf{P}\left(\mathrm{PhSO}_{3}^{-}\right)_{4}$ & & & & & -0.12 & & -0.33 & -0.33 & -0.33 & -0.33 & \\
\hline $\mathbf{H}_{3} \mathbf{P}^{+}\left(\mathrm{PhSO}_{3}^{-}\right)_{4}$ & -0.11 & -0.11 & & & +0.05 & & & & -0.36 & -0.36 & \\
\hline $\mathbf{H}_{4} \mathbf{P}^{2+}\left(\mathrm{PhSO}_{3}^{-}\right)_{4}$ & +0.25 & +0.25 & +0.25 & +0.25 & +0.57 & +0.57 & & & & & \\
\hline$\left[\mathbf{H}_{4} \mathbf{P}^{2+}\left(\mathrm{PhSO}_{3}^{-}\right)_{4}\right]\left(\mathrm{H}_{2} \mathrm{O}\right)_{2}$ & +0.23 & +0.23 & +0.23 & +0.23 & $+0.5)$ & +0.51 & & & & & $-0.41(\mathrm{~A}, \mathrm{~B}, \mathrm{C}, \mathrm{D})$ \\
\hline $\mathbf{H}_{2} \mathbf{I}_{(\mathrm{i})} \mathbf{P}\left(\mathrm{PhSO}_{3}^{-}\right)_{4}$ & -0.32 & & & -0.31 & & +0.09 & & -0.37 & -0.36 & & \\
\hline $\mathbf{H}_{3} \mathbf{I} \mathbf{P}^{+}\left(\mathrm{PhSO}_{3}^{-}\right)_{4}$ & -0.25 & & & -0.24 & & +0.09 & & -0.34 & -0.39 & & \\
\hline $\mathbf{H}_{4} \mathbf{I P}^{2+}\left(\mathrm{PhSO}_{3}^{-}\right)_{4}$ & +0.14 & +0.18 & +0.13 & +0.12 & +0.32 & +0.50 & & & & & \\
\hline$\left[\mathbf{H}_{4} \mathbf{I P}^{2+}\left(\mathrm{PhSO}_{3}^{-}\right)_{4}\right]\left(\mathrm{H}_{2} \mathrm{O}\right)_{2}$ & +0.18 & +0.27 & +0.24 & +0.24 & +0.36 & +0.50 & & & & & $\begin{array}{l}-0.09(\mathrm{~A}) \\
-0.38(\mathrm{~B}) \\
-0.49(\mathrm{C}) \\
-0.36(\mathrm{D})\end{array}$ \\
\hline
\end{tabular}

Table 2. Deviation of pyrrole and pyrrolenine rings (dihedral angle) and intramolecular hydrogen atoms (distance) from different platforms meso-plane: $(+)$ if nitrogen atom is above the plane, $(-)$ if nitrogen atom is below the plane.

\begin{tabular}{cccccc}
\hline Compound & $m s$-plane & $\mathrm{A}(+)$ & $\mathrm{B}(-)$ & $\mathrm{C}(+)$ & $\mathrm{D}(-)$ \\
\cline { 2 - 5 } & & $5.87(0.05)$ & 6.74 & $5.87(+0.05)$ & 6.74 \\
\hline $\mathbf{H}_{2} \mathbf{P}\left(\mathrm{PhSO}_{3}^{-}\right)_{4}$ & 0.18 & $19.13(0.37)$ & $23.55(0.79)$ & $9.14(+0.38)$ & 17.22 \\
$\mathbf{H}_{3} \mathbf{P}^{+}\left(\mathrm{PhSO}_{3}^{-}\right)_{4}$ & 0.20 & $33.56(0.78)$ & $33.56(0.78)$ & $33.56(+0.78)$ & $33.56(0.78)$ \\
$\mathbf{H}_{4} \mathbf{P}^{2+}\left(\mathrm{PhSO}_{3}^{-}\right)_{4}$ & 0.20 & $32.10(0.79)$ & $32.10(0.79)$ & $32.10(+0.79)$ & $32.10(0.79)$ \\
{$\left[\mathbf{H}_{4} \mathbf{P}^{2+}\left(\mathrm{PhSO}_{3}^{-}\right)_{4}\right]\left(\mathrm{H}_{2} \mathrm{O}\right)_{2}$} & 0.20 & $21.53(0.59)$ & $11.80(0.20)$ & 11.32 & $14.66(0.31)$ \\
$\mathbf{H}_{2} \mathbf{I}_{(\mathbf{i})} \mathbf{P}\left(\mathrm{PhSO}_{3}\right)_{4}$ & 2.20 & $24.81(0.93)$ & $13.04(0.26)$ & 12.22 & $12.07(0.24)$ \\
$\mathbf{H}_{3} \mathbf{I}_{(\mathbf{e})} \mathbf{P}^{+}\left(\mathrm{PhSO}_{3}^{-}\right)_{4}$ & 2.20 & $34.35(0.94)$ & $27.26(0.68)$ & $25.73(+0.79)$ & $25.11(0.64)$ \\
$\mathbf{H}_{4} \mathbf{I} \mathbf{P}^{2+}\left(\mathrm{PhSO}_{3}^{-}\right)_{4}$ & 0.70 & $33.04(0.93)$ & $27.93(0.73)$ & $30.03(+0.87)$ & $26.58(0.70)$ \\
{$\left[\mathbf{H}_{4} \mathbf{I} \mathbf{P}^{2+}\left(\mathrm{PhSO}_{3}^{-}\right)_{4}\right]_{\left(\mathrm{H}_{2} \mathrm{O}\right)}$} & 0.58 & & & \\
\hline
\end{tabular}


ring unfolds at 21.53 degrees (Table 2). In addition, the IMHR and $\mathrm{H}-\pi$ interactions between $\beta$-protons and phenyl rings (dihedral angles with meso-plane are close to $40^{\circ}$ ), appre-

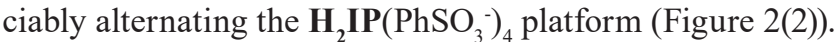

\section{Molecular Structure of $\boldsymbol{H}_{3} \mathrm{IP}^{+}\left(\mathrm{PhSO}_{3}^{-}\right)_{4}$}

$\mathrm{NH}$-tautomer $\mathbf{H}_{\mathbf{3}} \mathbf{I}_{(\mathbf{e})} \mathbf{P}^{+}\left(\mathrm{PhSO}_{3}^{-}\right)_{4}$ stabilized by IMHB is more stable, so external nitrogen atom of inverted ring is protonated first (Figure 3).

\section{Molecular Structure of $\boldsymbol{H}_{4} \mathbf{I P}^{2+}\left(\mathrm{PhSO}_{3}^{-}\right)_{4}$}

Further $\mathbf{H}_{3} \mathbf{I}_{(\mathbf{e})} \mathbf{P}^{+}\left(\mathrm{PhSO}_{3}^{-}\right)_{4}$ protonation leads to substitution of a IMHB for the IMHR. Perimeter of the aromatic conjugation circuit is expanding, and, as a result, the flexibility of $\mathbf{H}_{4} \mathbf{I} \mathbf{P}^{2+}$ molecular core increased (Figure 3 ). The $\mathbf{H}_{4} \mathbf{I P}^{2+}\left(\mathrm{PhSO}_{3}{ }_{4}^{-}\right.$platform is a elastic 1,3-alternate in which IMHR is balanced by the natural tendency of the aromatic system to planarity. The contribution of $\mathrm{H}-\pi$ interactions between $\beta$-protons and phenyl rings leads to an additional increase in intramolecular HH-distances, which in $\mathbf{H}_{4} \mathbf{I} \mathbf{P}^{2+}\left(\mathrm{PhSO}_{3}\right)_{4}$ transcends the sum of hydrogen atoms van der Waals radii $\mathrm{R}_{\mathrm{w}}(\mathrm{H})$.

The $\mathbf{H}_{4} \mathbf{I} \mathbf{P}^{2+}$ platform, as well as $\mathbf{H}_{4} \mathbf{P}^{2+}$, possesses molecular and anion receptor properties. ${ }^{[9,34-39]}$ Receptor $\mathbf{H}_{4} \mathbf{I P}^{2+}\left(\mathrm{PhSO}_{3}^{-}\right)_{4}$ has accessible HB-donor NH-groups, which along with delocalized ring charge form two sites of H-bonding "guests" in complexes "double roost" type. ${ }^{[37]}$ The internal weakly polar $\mathrm{CH}$-group generates the inequality of these two binding sites. A porphyrin-type site with a pair of converging NH-groups is pre-arranged for synergistic hydrogen and electrostatic binding of the contact oxygen atom with the geometric configuration $\mathrm{AX}_{2} \mathrm{E}_{2}$, while the inverted site with one NH-group is a monodentate. Inversion of pyrrole ring improves the complementarity of the porphyrin-type site of the receptor $\mathbf{H}_{4} \mathbf{I P}^{2+}\left(\mathrm{PhSO}_{3}{ }_{4}^{-}\right.$to the water molecule as compared to $\mathbf{H}_{4} \mathbf{P}^{2+}\left(\mathrm{PhSO}_{3}{ }_{4}^{-}\right)$. This is indicated by the higher value of the charge transferred from the bound water molecule to the receptor, -0.160 and -0.139 (Mulliken charges), respectively, while for the inverted site this value is only -0.106 . As a result, the total charge transferred from water molecules to the inverted receptor is slightly less $(-0.266$ and -0.279 , respectively) and hardly influence on relative stability of the $\left[\mathbf{H}_{4} \mathbf{I P}^{2+}\left(\mathrm{PhSO}_{3}^{-}\right)_{4}\right]\left(\mathrm{H}_{2} \mathrm{O}\right)_{2}$ complex as compared with $\left[\mathbf{H}_{4} \mathbf{P}^{2+}\left(\mathrm{PhSO}_{3}^{-}\right)_{4}\right]\left(\mathrm{H}_{2} \mathrm{O}\right)_{2}$. This fact implied a total shift in the equilibrium of the $\mathbf{H}_{2} \mathbf{I}_{(\mathbf{i})} \mathbf{P}\left(\mathrm{PhSO}_{3}^{-}\right)_{4}$ second protonation stage in water to the double aquacomplex, as well as for $\left[\mathbf{H}_{4} \mathbf{P}^{2+}\left(\mathrm{PhSO}_{3}{ }_{4}^{-)}\right]\left(\mathrm{H}_{2} \mathrm{O}\right){ }_{2} \cdot{ }^{[34,38]}\right.$

\section{Equilibria of $\boldsymbol{H}_{2} \mathbf{I}_{(i)} \boldsymbol{P}\left(\mathrm{PhSO}_{3}^{-}\right)_{4}$ Protonation with Perchloric} Acid in Water

For protonation of $\mathbf{H}_{2} \mathbf{I}(\mathbf{i}) \mathbf{P}\left(\mathrm{PhSO}_{3}^{-)}{ }_{4}\right.$ in water perchloric acid have been used, in which indifferent anion is not able to extrude water from aquacomplex $\left[\mathbf{H}_{4} \mathbf{P}^{2+}\left(\mathrm{PhSO}_{3}{ }^{-}\right)_{4}\right]\left(\mathrm{H}_{2} \mathrm{O}\right)_{2}$. [36] Acidification of the $\mathbf{H}_{2} \mathbf{I}(\mathbf{i}) \mathbf{P}\left(\mathrm{PhSO}_{3}^{-}\right)_{4}$ aqueous solution is accompanied by a synchronous two-step response in the absorption and fluorescence (weak intensity) spectra (Figure 4(1)).

Analysis of the results showed the presence of two individual protolytic equilibria (1) and (2), with the own families of isosbestic points and linear parts on AA dependencies (Figure 4(2)), which strictly obey the equation (6) in the $\mathrm{p} H$ ranges $2.00-6.18$ and $6.80-10.00$, but are violated in the transition $\mathrm{p} H$ region $6.18-6.80$, where three lightabsorbing centers are simultaneously presented.
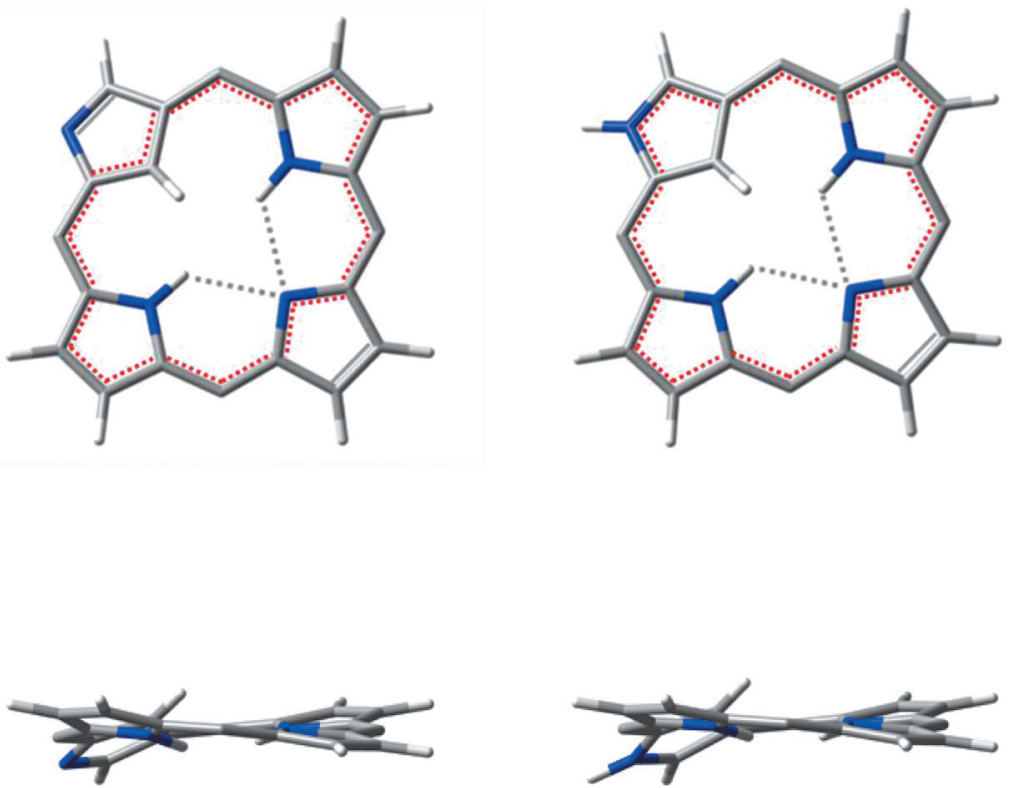

$\mathbf{H}_{\mathbf{2}} \mathbf{I}_{(\mathbf{i})} \mathbf{P}\left(\mathrm{PhSO}_{3}^{-}\right)_{4}$

$$
\mathbf{H}_{3} \mathbf{I}_{(\mathbf{e})} \mathbf{P}^{+}\left(\mathrm{PhSO}_{3}^{-}\right)_{4}
$$
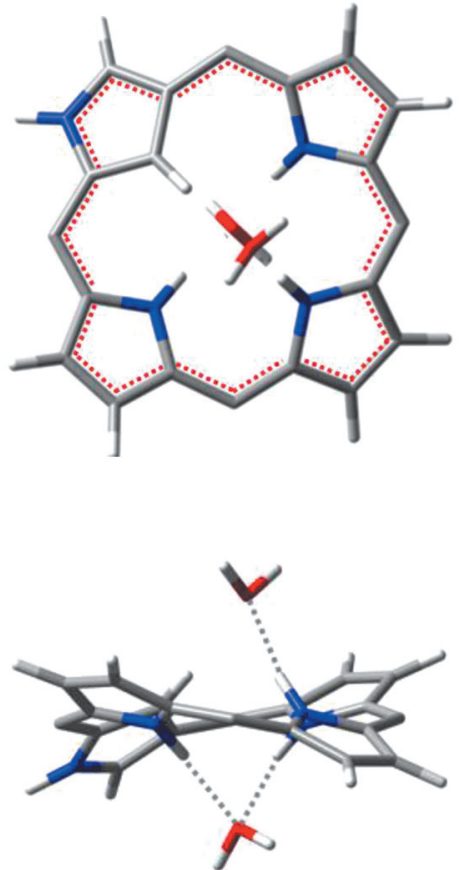

$\left[\mathbf{H}_{4} \mathbf{I P}^{2+}\left(\mathrm{PhSO}_{3}^{-}\right)_{4}\right]\left(\mathrm{H}_{2} \mathrm{O}\right)_{2}$

Figure 3. DFT-optimized geometry of inverted platform $\mathbf{H}_{2} \mathbf{I}_{(\mathbf{i})} \mathbf{P}\left(\mathrm{PhSO}_{3}^{-}\right)_{4}$ and its protonated forms (Tables 1, 2). meso-Substituents are omitted for clarity. Red dashed line - aromatic $18 \pi$-electron conjugated cycle. Gray dashed line - bifurcated IMHB. 

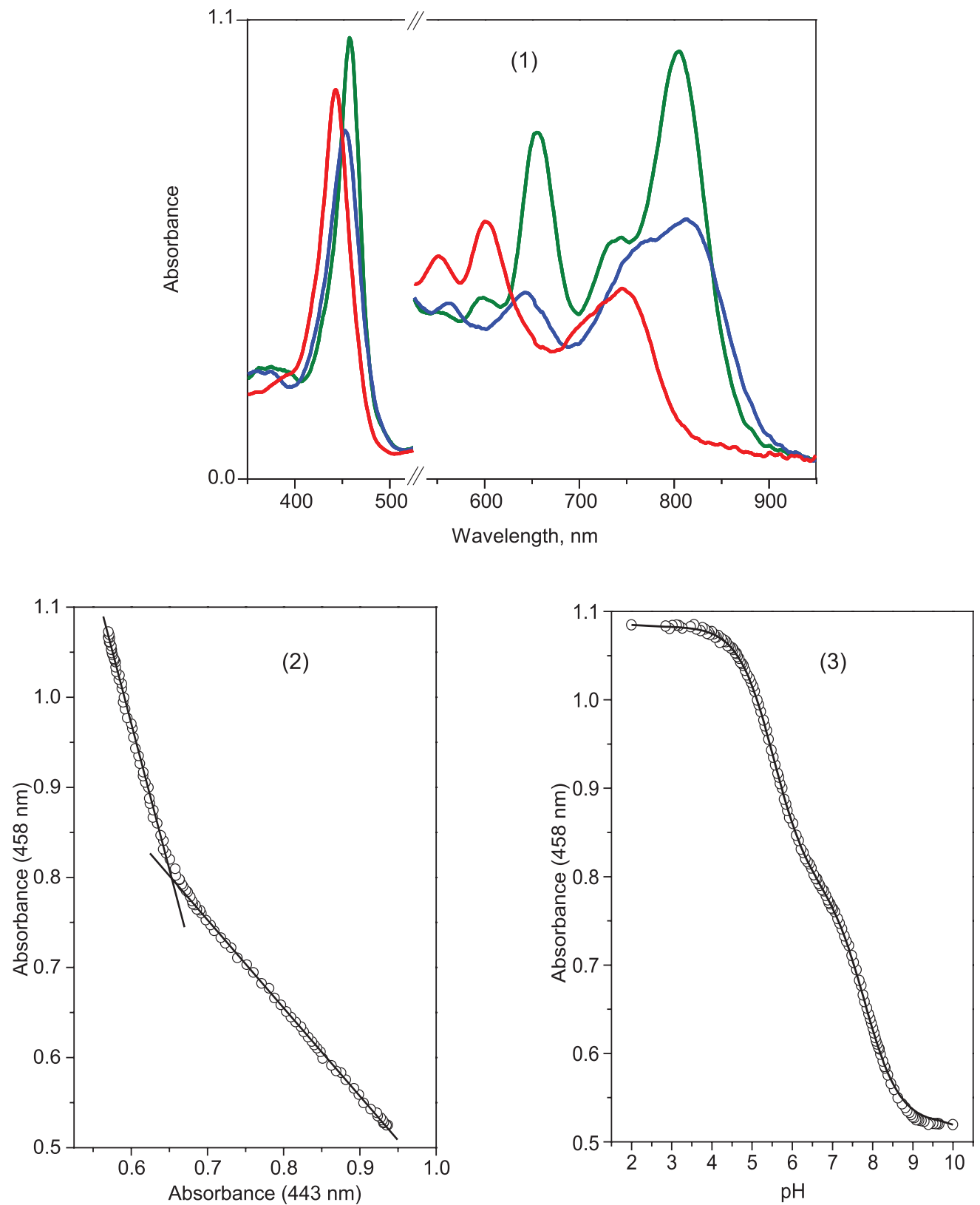

Figure 4. (1) - UV-Vis spectra of aqueous solutions $\mathbf{H}_{2} \mathbf{I}_{(\mathrm{i})} \mathbf{P}\left(\mathrm{PhSO}_{3}^{-}\right)_{4}($ red: $443 ; 552 ; 603$ and $746 \mathrm{~nm}), 87 \% \mathbf{H}_{3} \mathbf{I}_{(\mathrm{e})} \mathbf{P}^{+}\left(\mathrm{PhSO}_{3}^{-}\right)_{4}$ in mixture with conjugated forms: (blue: 453; 567; 647 and $811 \mathrm{~nm})$, $\left[\mathbf{H}_{4} \mathbf{I P}^{2+}\left(\mathrm{PhSO}_{3}\right)_{4}\right)_{(}\left(\mathrm{H}_{2} \mathrm{O}\right)_{2}$ (green: 458; 599; 654 and $\left.807 \mathrm{~nm}\right),(2)-$ correlation between absorbance at $443 \mathrm{~nm}$ and $458 \mathrm{~nm}(\mathrm{AA}),(3)$ - titration curve at $458 \mathrm{~nm}$.

$\mathbf{H}_{2} \mathbf{I}_{(\mathbf{i})} \mathbf{P}\left(\mathrm{PhSO}_{3}^{-}\right)_{4}+\mathrm{H}^{+} \stackrel{\mathrm{K}_{\mathrm{b} 1}}{\rightleftarrows} \mathbf{H}_{3} \mathbf{I}_{(\mathbf{e})} \mathbf{P}^{+}\left(\mathrm{PhSO}_{3}^{-}\right)_{4}$

$\mathbf{H}_{3} \mathbf{I}_{(\mathbf{e})} \mathbf{P}^{+}\left(\mathrm{PhSO}_{3}^{-}\right)_{4}+\mathrm{H}^{+} \stackrel{\mathrm{K}_{\mathrm{B} 2}}{\rightleftarrows}\left[\mathbf{H}_{4} \mathbf{I P}^{2+}\left(\mathrm{PhSO}_{3}^{-}\right)_{4}\right]\left(\mathrm{H}_{2} \mathrm{O}\right)_{2}$

$\mathbf{H}_{\mathbf{3}} \mathbf{I}_{(\mathrm{e})} \mathbf{P}^{+}\left(\mathrm{PhSO}_{3}^{-}\right)_{4}+\mathrm{H}^{+} \stackrel{\mathrm{K}_{\mathrm{b} 2}}{\rightleftarrows} \mathbf{H}_{4} \mathbf{I P}^{2+}\left(\mathrm{PhSO}_{3}^{-}\right)_{4}$

$\mathbf{H}_{4} \mathbf{I P}^{2+}\left(\mathrm{PhSO}_{3}^{-}\right)_{4}+2 \mathrm{H}_{2} \mathrm{O} \stackrel{\mathrm{K}_{\mathrm{wl}, 2}}{\rightleftarrows}\left[\mathbf{H}_{4} \mathbf{I P}^{2+}\left(\mathrm{PhSO}_{3}^{-}\right)_{4}\right]\left(\mathrm{H}_{2} \mathrm{O}\right)_{2}$

$K_{B_{2}}=K_{b 2} \cdot K_{w 1,2} \cdot C_{H_{2} \mathrm{O}}^{2} \quad\left(C_{\mathrm{H}_{2} \mathrm{O}}-\right.$ concentration of water in water)

$$
\frac{A_{\lambda 1}}{A_{\lambda 2}}=\frac{\varepsilon_{1}}{\varepsilon_{2}}
$$

$$
\begin{gathered}
A_{\lambda}=\frac{A_{0\left(H_{2} I_{(i)} P\right)}+A_{0_{\left(H_{3} I_{(e)} P^{+}\right)}} \cdot K_{b 1} \cdot 10^{-p H}}{1+K_{b 1} \cdot 10^{-p H}+K_{b 1} \cdot K_{B 2} \cdot 10^{-p H}}+ \\
+\frac{A_{0_{\left(\left[H_{4} I P^{2+}\right]\left(H_{2} O\right)\right)} \cdot K_{b 1} \cdot K_{B 2} \cdot 10^{-2 p H}}^{1+K_{b 1} \cdot 10^{-p H}+K_{b 1} \cdot K_{B 2} \cdot 10^{-p H}}}{}+
\end{gathered}
$$

where $A_{i}$ - current value, $A_{0 i}$ - absorbance of inverted porphyrin $i$-form solution with concentration $C_{o}$ on analytic wavelength $\lambda$.

The protonation constants of the inverted platform $\mathbf{H}_{2} \mathbf{I}_{(\mathbf{i})} \mathbf{P}\left(\mathrm{PhSO}_{3}^{-}\right)_{4} K_{b 1}$ and $K_{B 2}$ (in literature $K_{B 2}$ is taken as $K_{b 2}$ ) in water (Table 3 ) were calculated by fitting the parameters in equation (7) of the two-step titration curve (Figure 4(3)), as described for $\mathbf{H}_{2} \mathbf{P}\left(\mathrm{PhSO}_{3}\right)_{4}{ }^{[38]}$ as a constant $C_{H 2 O}$ $\left(\lg C_{H 2 O}=1.74 \mathrm{~mol} / \mathrm{L}\right.$ for pure water at $\left.25{ }^{\circ} \mathrm{C}\right)$ approxima- 
Table 3. The reactions (1)-(4) constants in water and corresponding enthalpies, calculated in gaseous phase.

\begin{tabular}{ccccccccc}
\hline Compound & $\lg K_{b 1}$ & $\lg K_{B 2}$ & $\lg \left(K_{b 2} K_{w 1,2}\right)$ & $\Delta H_{b 1}$ & $\Delta H_{b 2}$ & $\Delta H_{b 2} \Delta H_{w 1,2}$ & $\lg K_{b 1}-\lg \left(K_{b 2} K_{w 1,2}\right)$ & $\Delta H_{b 1}-\Delta H_{b 2} \Delta H_{w 1,2}$ \\
\hline $\mathbf{H}_{2} \mathbf{P}\left(\mathrm{PhSO}_{3}\right)_{4}{ }^{[38]}$ & $4.85 \pm 0.03$ & $4.71 \pm 0.03$ & 1.22 & -387.40 & -330.51 & -351.10 & 3.63 & -36.30 \\
$\mathbf{H}_{2} \mathbf{I}_{(\mathbf{i})} \mathbf{P}\left(\mathrm{PhSO}_{3}\right)_{4}$ & $\begin{array}{c}7.84 \pm 0.04 ; \\
\left(7.7^{[21]}\right)^{*}\end{array}$ & $\begin{array}{c}5.57 \pm 0.06 ; \\
\left(5.8^{[21]}\right)^{*}\end{array}$ & 2.08 & -399.34 & -333.44 & -349.55 & 5.76 & -49.79 \\
\hline
\end{tabular}

* - volume titration of $\mathbf{H}_{2} \mathbf{I P}\left(\mathrm{PhSO}_{3} \mathrm{Na}\right)_{4}$ with methanesulfonic acid

tion. For $\mathbf{H}_{2} \mathbf{I}_{(\mathbf{i})} \mathbf{P}\left(\mathrm{PhSO}_{3}^{-}\right)_{4}$ and $\mathbf{H}_{2} \mathbf{P}\left(\mathrm{PhSO}_{3}^{-}\right)_{4}$ a good agreement between the constants of reactions (1)-(4), measured in water, and the corresponding DFT enthalpies, calculated in the absence of the medium (Table 3), was found

$\mathbf{H}_{2} \mathbf{I}_{(\mathbf{i})} \mathbf{P}\left(\mathrm{PhSO}_{3}^{-}\right)_{4}$ is a stronger base and possesses a higher proton affinity, so protonation begins already in the alkaline $\mathrm{pH}$ region. A different diprotonation scheme for the inverted platform and the weaker aquacomplex $\left[\mathbf{H}_{4} \mathbf{I P}^{2+}\left(\mathrm{PhSO}_{3}{ }^{-}\right)_{4}\right]\left(\mathrm{H}_{2} \mathrm{O}\right)_{2}$ are the reasons for the increase in the difference between step enthalpies $\Delta H_{b 1}-\Delta H_{b 2} \Delta H_{w 1,2}$, calculated without medium consideration and the corresponding protonation constants $\lg K_{b 1}-\lg \left(K_{b 2} K_{w 1,2}\right)$ in water. As a result, the anomalous proximity of the $\mathbf{H}_{2} \mathbf{P}\left(\mathrm{PhSO}_{3}^{-}\right)_{4}$ stepwise diprotonation constants in water, due to the aquacomplex formation, is withdrawing for inverted derivative $\mathbf{H}_{2} \mathbf{I}(\mathbf{i}) \mathbf{P}\left(\mathrm{PhSO}_{3}^{-}\right)_{4}$ and leads to appearing two clear steps on corresponding titration curves.

Aquacomplex $\left[\mathbf{H}_{4} \mathbf{I} \mathbf{P}^{++}\left(\mathrm{PhSO}_{3}^{-}\right)_{4}\right]\left(\mathrm{H}_{2} \mathrm{O}\right)_{2}$, resulting from the diprotonation of the inverted platform, is the monomer of supramolecular $J$-aggregates self-assembly. The driving force of the $J$-aggregates self-assembly is the more stable anion complexes formation as a result of intermolecular substitution of the bound water molecules by the phenylsulfonate groups (Figure 5).

\section{Conclusions}

1. In aqueous solution $\mathbf{H}_{2} \mathbf{I P}\left(\mathrm{PhSO}_{3}^{-}\right)_{4}$ exists as $\mathrm{NH}$-tautomer $\mathbf{H}_{2} \mathbf{I}(\mathbf{i}) \mathbf{P}\left(\mathrm{PhSO}_{3}^{-}\right)_{4}$ with inverted pyrrolenine ring, stabilized by bifurcated IMHB between two pyrrole hydrogens and one pyrrolenine nitrogen. IMHB protects intramolecular centers of hydrogen bonding from intermolecular interactions.

2. Inversion of pyrrolenine ring leads to increasing of proton affinity, and, as a result, basicity of $\mathbf{H}_{2} \mathbf{I}_{(\mathbf{i})} \mathbf{P}\left(\mathrm{PhSO}_{3}^{-}\right)_{4}$.

3. Sequence of protonation of main centers in the inverted platform $\mathbf{H}_{2} \mathbf{I} \mathbf{P}\left(\mathrm{PhSO}_{3}^{-}\right)_{4}$ is determined by intramolecular hydrogen bonds at the first protonation stage and intermolecular hydrogen bonds at the second protonation stage.

4. The $\mathbf{H}_{4} \mathbf{I P}^{2+}\left(\mathrm{PhSO}_{3}^{-}\right)_{4}$ diprotonated platform is elastic 1,3-alternate, which possesses anion and molecular receptor properties. Equilibrium of the $\mathbf{H}_{2} \mathbf{I}_{(\mathbf{i})} \mathbf{P}\left(\mathrm{PhSO}_{3}^{-}\right)_{4}$ second protonation stage in water is total shifted to the aquacomplex $\left[\mathbf{H}_{4} \mathbf{I P}^{2+}\left(\mathrm{PhSO}_{3}^{-}\right)_{4}\right]\left(\mathrm{H}_{2} \mathrm{O}\right)_{2}$ formation due to hydrogen and electrostatic binding of solvent molecules at two receptor sites.

5. Aquacomplex $\left[\mathbf{H}_{4} \mathbf{I} \mathbf{P}^{++}\left(\mathrm{PhSO}_{3}^{-}\right)_{4}\right]\left(\mathrm{H}_{2} \mathrm{O}\right)_{2}$ is the monomer of supramolecular $J$-aggregates self-assembly. The driv-
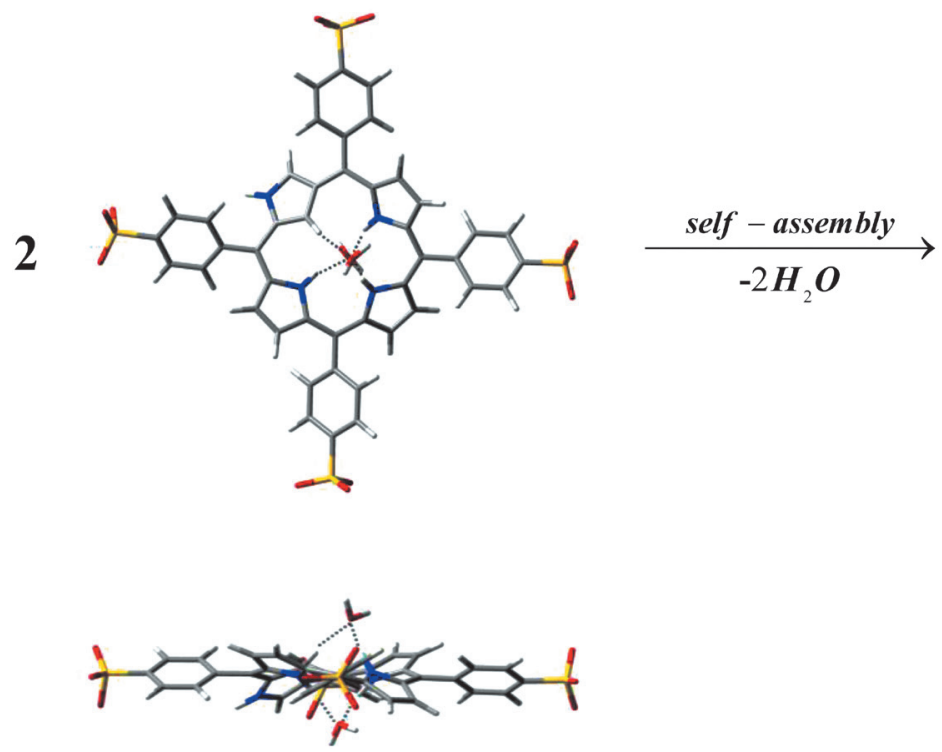

monomer
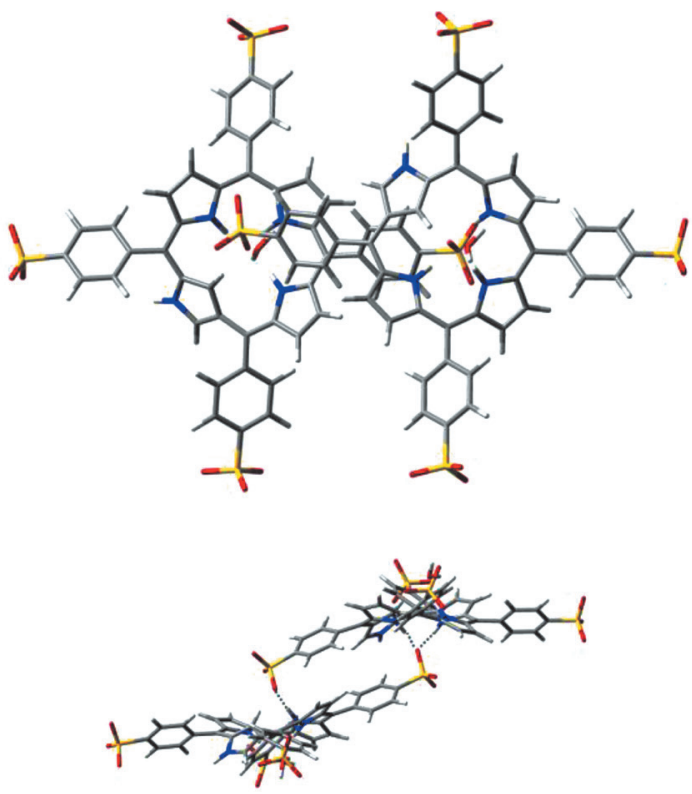

$J$-dimer

Figure 5. Scheme of $J$-aggregates $\left.\mathbf{H}_{4} I \mathbf{P}^{2+}\left(\mathrm{PhSO}_{3}^{-}\right)_{4}\right]\left(\mathrm{H}_{2} \mathrm{O}\right)_{2}$ self-assembly by intermolecular substitution of the bound water molecules by the phenylsulfonate groups. 
ing force of the $J$-aggregates self-assembly is more stable anion complexes formation as a result of intermolecular substitution of the bound water molecules by the phenylsulfonate groups.

Acknowledgement. Presented work was supported by Russian Science Foundation (Project № 14-23-00204-P).

\section{References}

1. Purrello R., Gurrieri S., Lauceri R. Coord. Chem. Rev. 1999, 192, 683-706.

2. Goldberg I. CrystEngComm 2002, 4, 109-116.

3. Bell T.W., Hext N.M. Chem. Soc. Rev. 2004, 33, 589-598.

4. Monti D., Nardis S., D’Amico A., Stefanelli M., Paolesse R., Di Natale C. Journal of Sensors 2009, Article ID 856053, 10 pages.

5. Dini F., Martinelli E., Pomarico G., Paolesse R., Monti D., Filippini D., D'Amico A., Lundstrom I., Di Natale C. Nanotechnology 2009, 20, 5502.

6. Veselov A., Thur C., Efimov A., Guina M., Lemmetyinen H., Tkachenko N. Meas. Sci. Technol. 2010, 21, 115205.

7. Selyanchyn R., Korposh S., Wakamatsu S., Lee S-W. Sensors 2011, 11, 1177-1191.

8. Webb M.J., Bampos N. Chem. Sci. 2012, 3, 2351-2366.

9. Ishihara S., Minami K., Labuta J., Hill J.P., Van Rossom W., Ariga K., Ishikawa D. Phys. Chem. Chem. Phys. 2014, 16, 9713-9746.

10. Sheinin V.B., Bobritskaya E.V., Shabunin S.A., Koifman O.I. Macroheterocycles 2014, 7, 209-217.

11. Xie J., Chen X., Huang Z., Zuo T. J. Mol. Model. 2015, 21, 140.

12. Mihara N., Yamada Y., Furukawa K., Kato T., Tanaka K. Dalton Trans. 2018, 47, 7044-7049.

13. Medforth C.J., Wang Z., Martin K.E., Song Y., Jacobsen J.L., Shelnutt J.A. Chem. Commun. 2009, 47, 7261-7277.

14. Shelnutt J.A., Medforth C.J. Organic Nanomaterials: Synthesis, Characterization, and Device Applications, First Edition. John Wiley \& Sons, Inc. Published, 2013. 103 p.

15. Furuta H., Asano T., Ogawa T. J. Am. Chem. Soc. 1994, 116, 767-768.

16. Chmielewski P.J., Latos-Grazyński L., Rachlewicz K., Glowiak T. Angew. Chem., Int. Ed. Engl. 1994, 33, 779-781.

17. Moriyama S., Ikawa Y., Furuta H. Nucleic Acids Symposium Series 2007, 51, 207-208.
18. Ikawa Y., Moriyama S., Harada H., Furuta H. Org. Biomol. Chem. 2008, 6, 4157-4166.

19. Ikawa Y., Ogawa H., Harada H., Furuta H. Bioorg. Med. Chem. Lett. 2008, 18, 6394-6397.

20. Thomas A.P., Babu P.S.S., Nair S.A., Ramakrishnan S., Ramaiah D., Chandrashekar T.K., Srinivasan A., Pillai M.R. J. Med. Chem. 2012, 55, 5110-5120.

21. Shaw J.L., McMurry J.L., Salehi P., Stovall A. J. Porphyrins Phthalocyanines 2014, 18, 231-239.

22. Ou Z., Chen X., Ye L., Xue S., Fang Y., Jiang X., Kadish K.M. J. Porphyrins Phthalocyanines 2015, 19, 251-260.

23. Xue S., Ou Z., Ye L., Lu G., Fang Y., Jiang X., Kadish K.M. Chem. Eur. J. 2015, 21, 2651-2661.

24. Sakashita R., Ishida M., Furuta H. J. Phys. Chem. A 2015, 119 , 1013-1022.

25. Ikawa Y., Katsumata S., Sakashita R., Sato S., Takenaka S., Furuta H. J. Porphyrins Phthalocyanines 2016, 20, 1041-1048.

26. Chmielewski P.J., Latos-Grażyński L. J. Chem. Soc., Perkin Trans 2 1995, 3, 503-509.

27. Sheinin V.B., Kulikova O.M., Aleksandriiskii V.V., Koifman O.I. Macroheterocycles 2016, 9, 353-360.

28. Geier G.R., Haynes D.M., Lindsey J.S. Org. Lett. 1999, 1, 1455-1458.

29. Frisch M.J., Trucks G.W., Schlegel H.B., et al., Gaussian 09, Revision A.02 (Gaussian Inc., Wallingford CT, 2009).

30. Sakashita R., Ishida M., Furuta H. J. Phys. Chem. A 2015, 119, 1013-1022.

31. Gua C.-H., Lib H., Gandhia R.B., Raghavana K. Int. J. Pharm. 2004, 283, 117-125.

32. Alema E.A., Joseph J., Modarelli D.A. J. Org. Chem. 2015, 80, 11031-11038.

33. Etter M.C. Acc. Chem. Res. 1990, 23, 120-126.

34. Sheinin V.B., Ivanova Yu.B., Berezin B.D. Russ. J. Coord. Chem. 2002, 28, 149-151.

35. Sheinin V.B., Ivanova Yu.B., Berezin B.D. Russ. J. Gen. Chem. 2002, 72, 1128-1131.

36. Sheinin V.B., Simonova O.R., Ratkova E.L. Macroheterocycles $\mathbf{2 0 0 8}, 1,72-78$.

37. Sheinin V.B., Ratkova E.L., Mamardashvili N.Zh. J. Porphyrins Phthalocyanines 2008, 12, 1211-1219.

38. Sheinin V.B., Shabunin S.A., Bobritskaya E.V., Koifman O.I Macroheterocycles 2011, 4, 80-84.

39. Sheinin V.B., Shabunin S.A., Bobritskaya E.V., Ageeva T.A., Koifman O.I. Macroheterocycles 2012, 5, 252-259.

40. Batsanov S.S. Inorg. Mater. 2001, 37, 871-885. 